\title{
Modeling potential habitats for Pergularia tomentosa using maximum entropy model and effect of environmental variables on its quantitative characteristics in arid rangelands, southeastern Iran
}

Seyed Hamzeh Hosseini ${ }^{*}$, Hossein Azarnivand ${ }^{2}$, Mahdi Ayyari ${ }^{3}$, Mohammad Ali Zare Chahooki ${ }^{2}$, Reza Erfanzadeh ${ }^{4}$, Sonia Piacente ${ }^{5}$ and Reza Kheirandish ${ }^{6}$

\begin{abstract}
Background: Predicting the potential habitat of plants in arid regions, especially for medicinal ones, is very important. Although Pergularia tomentosa is a key species for medicinal purposes, it appears in very low density in the arid rangelands of Iran, needing an urgent ecological attention. In this study, we modeled and predicted the potential habitat of $P$. tomentosa using maximum entropy, and the effects of environmental factors (geology, geomorphology, altitude, and soil properties) on some characteristics of the species were determined.

Results: The results showed that $P$. tomentosa was absent in igneous formation while it appeared in conglomerate formation. In addition, among geomorphological units, the best quantitative characteristics of $P$. tomentosa was belonged to the conglomerate formation-small hill area (plant aerial parts $=57.63$ and root length $=30.68 \mathrm{~cm}$ ) with the highest electrical conductivity, silt, and $\mathrm{CaCO}_{3}$ content. Conversely, the species was not found in the mountainous area with igneous formation. Moreover, plant density, length of roots, and aerial parts of the species were negatively correlated with soil sand, while positive correlation was observed with $\mathrm{CaCO}_{3}$, EC, potassium, and silt content. The maximum entropy was found to be a reliable method $(\mathrm{ROC}=0.91)$ for predicting suitable habitats for P. tomentosa.

Conclusion: These results suggest that in evaluating the plant's habitat suitability in arid regions, contrary to the importance of the topography, some environmental variables such as geomorphology and geology can play the main role in rangeland plants' habitat suitability.
\end{abstract}

Keywords: Arid rangelands, Environmental variables, Quantitative plant characteristics, Habitat suitability, Maximum entropy, Pergularia tomentosa

\footnotetext{
* Correspondence: s.hamzeh.hossaini@gmail.com; Hamze@ujiroft.ac.ir

${ }^{1}$ Department of Plant Biology, University of Jiroft, Jiroft, Kerman Province, Iran

Full list of author information is available at the end of the article
}

(c) The Author(s). 2018 Open Access This article is distributed under the terms of the Creative Commons Attribution 4.0 International License (http://creativecommons.org/licenses/by/4.0/), which permits unrestricted use, distribution, and reproduction in any medium, provided you give appropriate credit to the original author(s) and the source, provide a link to the Creative Commons license, and indicate if changes were made. The Creative Commons Public Domain Dedication waiver (http://creativecommons.org/publicdomain/zero/1.0/) applies to the data made available in this article, unless otherwise stated. 


\section{Background}

In arid rangelands of Iran, medicinal plants such as Pergularia tomentosa (from the Apocynaceae family, Asclepiadeae) have a great value for local inhabitants and potential use in the pharmaceutical industry (Hosseini Kahnouj et al. 2017). Consequently, this plant is an important species in southern and southeastern Iran (Soltanipur 2005). This plant is also native to other countries in arid regions such as Saudi Arabia, Egypt, Afghanistan, Pakistan, and Sudan, and different uses were reported around the world (e.g., Babaamer et al. 2012; Al-Said et al. 2002).

Traditional medicinal uses of $P$. tomentosa include tanning (Heneidak et al. 2006), depilation (Bellakhdar 1998), as an abortifacient, for scorpion bites and poultices on snake bites (Babaamer et al. 2013; Hammiche and Maiza 2006), for addressing tuberculosis and molluscicidal activity (Hussein et al. 1999), for treating constipation (Arafa et al. 2006), as an anti-inflammatory (Al-Jabri 2013), and mixed with salt to remove hair from infected skin areas (Al-Said et al. 2002). According to previous studies, this species has evident effects such as antidermatophytic activity (Shinkafi 2014), anticancer agent (Piacente et al. 2009), insect repellant (Green et al. 2011), antioxidant (Yakubu et al. 2015), and fungicide (Bekheet et al. 2011).

Despite several useful applications in southern and southeastern Iran, a low percentage of the rangeland surface is naturally vegetated with $P$. tomentosa. Our field survey confirmed that this species were being used by native people while the species had not a salient distribution. Moreover, the plant's survival encounters severe limitations due to inhabitants uproot the plant to meet their needs. Hence, conservation measures to protect the remaining plant individuals and to increase their numbers are essential.

It is well known that the conservation and extension of plant species without identifying their ecological needs are not acceptable. Our literature review showed that ecological studies on this species are scarce. The only ecological study on P. tomentosa in Iran demonstrated that the canopy of shrubby plants has significant effect in the improvement of soil seed bank richness and density of P. tomentosa (Hosseini 2016). In another study, Al-Rowaily et al. (2015) showed that this plant is unpalatable for animals and livestock grazing could not negatively affect the species in Saudi Arabia.

Ecological niche models are used to determine correlative analysis of the environmental factors for predicting ecological requirements and relative suitability of habitats (Warren and Seifert 2011). Different plant species distribution models (ENFA, Maxent, GLM, and CLIMEX) are employed by researchers for the incidence data to predict suitable conditions for improving plants
(Kumar et al. 2009; Hosseini et al. 2013; Phillips et al. 2006; Byeon et al. 2018; Kumar et al. 2015; Jung et al. 2016). In this regard, maximum entropy (Maxent) is one of the best models for evaluating the relationships between the existence of species and environmental factors, especially for endangered plant species (Gogol-Prokurat 2011). Maxent is an empirical model for the occurrences of species in response to environmental prediction factors using statistically derived curves for the plant species' ecological tolerances (Guisan et al. 2007; Warren and Seifert 2011).

$P$. tomentosa is a plant which found widely in some parts of the Middle East (Gallacher and Hill 2006; Chaudhary and Le Houérou 2006; Al-Rowaily et al. 2015), but based on field visits and our previous research (Erfanzadeh et al. 2014; Erfanzadeh and Hosseini Kahnuj 2015; Hosseini 2016), negligible percentage of the eastern arid rangelands of Iran is vegetated by this plant. In addition, there are disturbing reports about the conservation status of this plant in other countries, particularly in the Horn of Africa (Goyder 2006). Therefore, the main aims of this study were to identify and predict the suitable habitat for $P$. tomentosa based on the geomorphological, geological factors, and soil physicochemical characteristics using statistical analysis and Maxent model. We also investigated the effects of environmental factors on some quantitative morphological characteristics of the plant species (height of aerial parts, length of roots, length of leaves, length of fruits, number of seeds, and density).

\section{Methods}

\section{Study area}

This research was conducted in the rangelands of Kahnouj, Kerman Province, Iran $\left(57^{\circ} 42^{\prime}\right.$ to $57^{\circ} 46^{\prime}$ E; $28^{\circ} 02^{\prime}$ to $28^{\circ} 06^{\prime} \mathrm{N}$ ) (Fig. 1) with a surface of 6771 ha. According to the Domarton's climatic classification, the climate is arid. The minimum monthly average temperature is $0{ }^{\circ} \mathrm{C}$ in January, rising to a maximum of $51{ }^{\circ} \mathrm{C}$ in July (Erfanzadeh et al. 2014). The variation in elevation in this region is about $600 \mathrm{~m}(500-1100 \mathrm{~m})$. The aboveground vegetation is mostly dominated by annuals in spring and shrubs in summer (Erfanzadeh and Hosseini Kahnuj 2015). The studied rangelands included Chah Godari, Koohe Sorkh, and Chah Pizg Janahmad Shahryari (Table 1).

There are large groups of rangeland beneficiaries in southeastern Iran concentrated around this area, including three cities, Kahnouj, Faryab, and Jiroft. The region has rich and diverse natural resources. Therefore, given these conditions and our previous studies, this case study was selected, featuring two geological formations (conglomerate and igneous) and five geomorphological units (small hill area, big hill area, bare plain, flood plain, and mountain). 


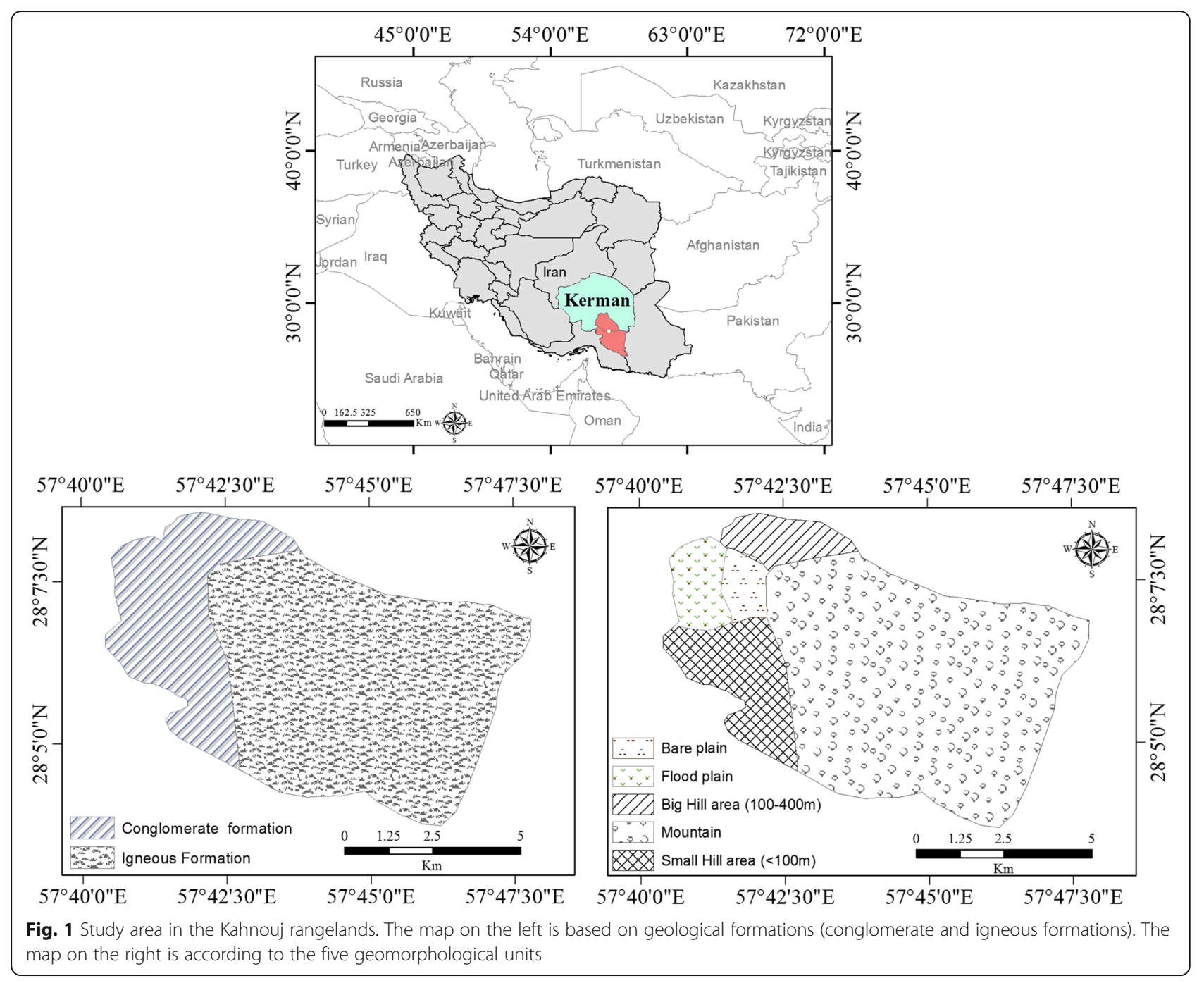

At the first step, three geomorphological units are distinguished in the study area (mountain, hill, and plain). The hill area was divided into two smaller units based on their heights. The plain was also dividable into bare plain and flood plain according to their slopes (bare plain: $3-8 \%$ slope; flood plain: about $2 \%$ slope). Moreover, bare plain had low density of plant species. We distinguished mountainous and hill areas based on their heights (mountainous area $>500 \mathrm{~m}$ height, big hill area: $100-400 \mathrm{~m}$ height, and small hill area $<100 \mathrm{~m}$ height).
Table 1 presents the areas belonging to each geological formation and geomorphological unit (Table 1). All methods and measured parameters regarding P. tomentosa appear in a diagram (Fig. 2).

\section{Sampling}

In order to model the habitat appropriately, study areas were selected according to the five geomorphological units (mountain, big hill area (100-400 m elevation), small hill area $(<100 \mathrm{~m}$ elevation), bare plain, and flood

Table 1 The study area (percentage of area and area in hectares) based on geological formation (conglomerate and igneous) and the five geomorphological units

\begin{tabular}{|c|c|c|c|c|c|}
\hline Environmental factors & Area (ha) & Area (\%) & Geomorphological unit & Area (ha) & Area (\%) \\
\hline Igneous & 4813.97 & 71.09 & Mountain & 4813.97 & 71.09 \\
\hline \multirow[t]{4}{*}{ Conglomerate } & 1957.54 & 28.90 & Small hill area $(<100 \mathrm{~m})$ & 854.29 & 12.61 \\
\hline & & & Bare plain & 106.46 & 1.57 \\
\hline & & & Flood plain & 329.51 & 4.86 \\
\hline & & & Big hill area (100-400 m) & 667.29 & 9.85 \\
\hline
\end{tabular}




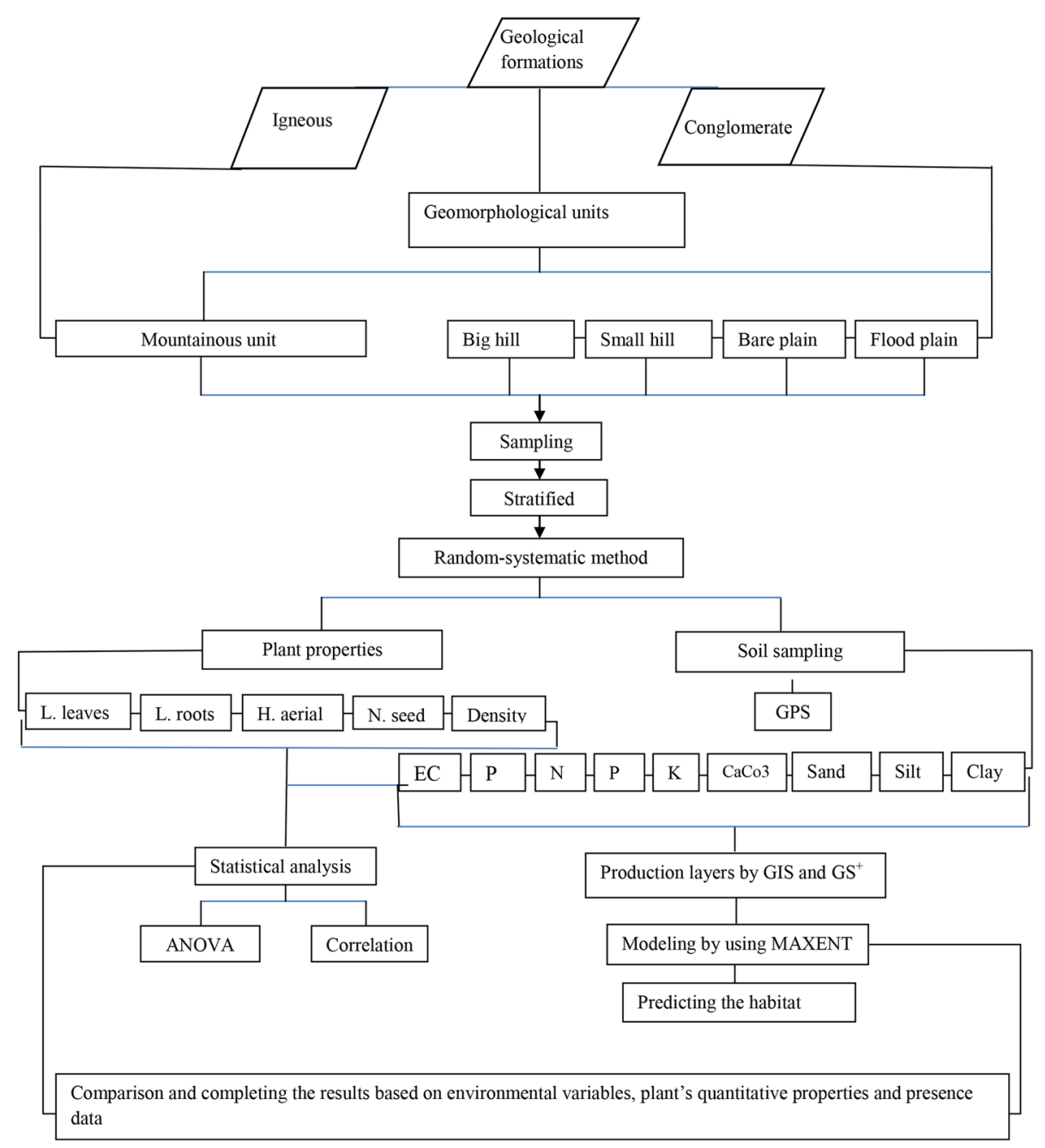

Fig. 2 Methods and measured parameters about $P$. tomentosa

plain) were distinguishable. These units were in accordance with the two geological formations. In this manner, small hill area $(<100 \mathrm{~m})$, big hill area $(100-400 \mathrm{~m})$, bare plain, and flood plain were located in the conglomerate formation, and mountain was situated in the igneous formation. Prior to the data sampling, the study area was stratified to five parts based on the geomorphological units, and with respect to the topographical conditions, each unit was divided into some sections. Subsequently, in each section (areas with similar condition based on the topography and vegetation in each geomorphological units), the first transect points were selected randomly and the rest were established systematically. The transects were $300 \mathrm{~m}$ long, and the distance between transects was determined based on topographic restrictions. In order to collect soil data and record the presence-absence of $P$. tomentosa, 201 sampling points (presence: 141 and absence: 60) were recorded using GPS. Furthermore, 98 soil samples from presence points and 60 samples from absence points (mountain: 58; bare plain: 2 samples) were taken at $0-30 \mathrm{~cm}$ depth, in initiating middle and ending points of each transect. The mass of each collected soil sample was about 700-800 g. Fifty-eight soil samples were taken from the absence area's 4813 ha; 98 samples were taken from the 1957 ha in the presence area due to its importance and increasing reliability of data. We measured some soil physicochemical parameters, i.e., $\mathrm{pH}$ determined via $\mathrm{pH}$ meter (Moled: Consort C860; Parklaan 36) and soil water ratio $=1.5$, texture analyzed by Bouyoucos hydrometer (Black 1979); $\mathrm{CaCO}_{3}$ (\%), determined by $1 \mathrm{~N}$ HCL (Jackson 1993), electrical conductivity in $\mathrm{dS} / \mathrm{m}$, determined using conductivity meter (Jackson 1993; Model: inolab Cond 7110; WTW), nitrogen ( $\mathrm{N} \%$ ) analyzed by the Kjeldahl method (Jackson 1967; Model: Distillation Unit K-350; BUCHI), phosphorus, in ppm, determined by the Olsen method (Lahiji et al. 2012) and potassium (K), in ppm, analyzed with a flame photometer (Model: PFP7 Flame; 
JENWAY), by the ammonium acetate extraction method (Lahiji et al. 2012).

In addition, we measured $P$. tomentosa quantitative characteristics (height of aerial parts, length of roots, length of leaves, length of fruits, number of seeds, and density) to determine the best ecological condition for species conservation goals. Some of these characteristics (height of aerial parts, length of roots, length of leaves, and length of fruits) were measured by a ruler. The number of seeds was counted for each fruit. The plant species density was calculated by belt transects, $300 \mathrm{~m}$ long and $10 \mathrm{~m}$ wide, yielding the number of $P$. tomentosa per hectare. Digital elevation model was produced from 1:25000 topographic maps of the National Cartographic Center of Iran (http://www.ncc.org.ir), Tehran, Iran. All environmental maps were created using geostatistical methods (Kriging method) with Z $30 \times 30 \mathrm{~m}$ spatial (Hosseini et al. 2013). For this purpose, ArcGIS 10.3 and GS+ were employed.

\section{Modeling habitat distribution}

Prediction of the potential distribution of $P$. tomentosa was accomplished via the Maxent modeling technique. Both Maxent and presence data were employed (Phillips et al. 2006; Elith et al. 2006). Researchers had sufficient knowledge about the study area through site exploration and frequent field visits (Erfanzadeh and Hosseini Kahnuj 2015; Erfanzadeh et al. 2014; Hosseini 2016). Soil sampling for the absence points, without $P$. tomentosa, particularly in the mountainous area, was done with high confidence. In other words, in the mountainous area located in the igneous formation, an absence area, soil samples were collected to demonstrate the absence of $P$. tomentosa based on the distinguishing environmental variables (soil parameters, geomorphological units, geological formations, and altitude). Then, environmental layers were evaluated based on the training data location and the probability of the occurrence of $P$. tomentosa in the entire study area (Buehler and Ungar 2001).

In general, when one pixel in the Maxent analysis had equal environmental conditions for the training data, higher values were defined to it (Hosseini et al. 2013). Predictive continuous layers were classified as binary ( 0 or 1$)$ or absence-presence data using equal test sensitivity and specificity. The jackknife operation was used to evaluate the importance of the environmental predictors (Hosseini et al. 2013). Indeed, developing and testing of the model required training and testing (two independent datasets); therefore, jackknife was used (Negga 2007).

\section{Receiver operating characteristic curves}

The area under the curve of the receiver operating characteristic (ROC) graph can be analyzed for simulating the results of the Maxent model. In the ROC curve, the
$Y$ and $X$ axes showed the true positive (sensitivity) and false positive (1-specificity) fractions, respectively (Fielding and Bell 1997). If the ROC curve shows maximum sensitivity for low values of the false positive fraction, the model is considered acceptable. This evaluation can be done by the area under the curve (AUC) (Hernández et al. 2006). The value of AUC is between 0.5 (true positives and false positives) and 1 (perfect differentiation) (Hosseini et al. 2013) and shows that the quantity accuracy of this model is independent of the thresholds (Deleo 1993).

\section{Response curves}

Response curves show the correlation between environmental factors and a plant's habitat suitability. These curves determine the relationship between each environmental factor and potential habitat suitability (Hosseini et al. 2013).

\section{Statistical analyses}

First, distribution of data investigated using One-Sample Kolmogorov-Smirnov Test. Then, one-way ANOVA and post hoc tests were used to analyze the quantitative characteristics (aerial height, root length, length of the leaves, length of fruits, number of seeds, and density) of $P$. tomentosa and physicochemical characteristics of the soil. Pearson correlation and multivariate regression were used to investigate the relationship between the environmental variables and quantitative characteristics of P. tomentosa.

\section{Results}

In general, the results showed that the highest percentage of the vegetation in the study area belonged to the shrub species while the diversity of these species was low. Also, the absence and presence of plant species were affected by the geomorphological units (Table 2). Moreover, as the data met normal distribution requirements (One-Sample Kolmogorov-Smirnov Test, $p>$ 0.05), parametric analyses were performed using SPSS version 17.

\section{The effect of geological formation}

The results showed that the average values of the aerial height, root length, length of the leaves, and length of fruits of $P$. tomentosa in conglomerate formation were $46.09 \mathrm{~cm}, 26.52 \mathrm{~cm}, 2.80 \mathrm{~cm}$, and $5.13 \mathrm{~cm}$, respectively. Density of $P$. tomentosa was 0.069 per hectare, and the average number of seeds in each fruit was 25.33. Note, however, that this plant species is unable to grow in igneous formation. 
Table 2 Absence (-) and presence (+) of Pergularia tomentosa and other plant species in the five geomorphological units

\begin{tabular}{|c|c|c|c|c|c|}
\hline Species & Mountain & Big hill area & Small hill area & Bare plain & Flood \\
\hline Aeluropus spp. & - & + & - & + & + \\
\hline Asphodelus tenuifolius L. & + & + & + & + & + \\
\hline Astragalus triboloides Dlile. & + & + & + & + & + \\
\hline Convolvolus leptocleidus L. & + & + & + & + & - \\
\hline Calligonum bungei Boiss. & - & - & - & - & + \\
\hline Euphorbia larica Boiss. & + & - & - & - & - \\
\hline Euphorbia spp. & + & - & - & - & - \\
\hline Fagonia bruguieri DC. & + & + & + & + & + \\
\hline Gaillonia aucheri Jaub. and Spach & - & - & + & + & + \\
\hline Gymnocarpus decanter Forssk. & + & + & + & - & - \\
\hline Hammada salicornicum Moq. & - & - & - & + & + \\
\hline Infloga spicata Boiss. & + & + & + & + & + \\
\hline Lycium edgeworthii, Dun. & + & + & + & + & + \\
\hline Malva neglecta $\mathrm{L}$. & + & + & + & + & + \\
\hline Prosopis cineraria L. & - & - & - & + & + \\
\hline Pistacia khinjuk Stocks. & + & - & - & - & - \\
\hline Pergularia tomentosa $\mathrm{L}^{*}$ & - & + & + & + & + \\
\hline Petropyrum aucheri Jaub. and Spach & - & - & - & + & + \\
\hline Pycnocycla spinosa Decne. \& Boiss. & + & + & + & + & + \\
\hline Plantago stocksii Boiss .and Decne. & + & + & + & + & + \\
\hline Rumex vesicarius $\mathrm{L}$. & + & + & + & + & + \\
\hline Rhazya stricta Decne. & - & - & + & + & + \\
\hline Scorzonera paradoxa Fisch. \& C.A. Mey. & + & + & + & + & + \\
\hline Suaeda spp. & + & - & - & - & + \\
\hline Stipa capensis Thunb. & + & + & + & + & + \\
\hline Taverniera cuneifolia (Roth) Arn. & + & + & + & + & + \\
\hline Ziziphus nummularia (Burm.f.)Wight \& Arn. & + & + & + & + & + \\
\hline Ziziphus spina-christi (L.)Willd. & - & - & - & + & + \\
\hline Zygophyllum eurypterum Bioss \& Buhse. & + & + & - & - & - \\
\hline
\end{tabular}

\section{Physicochemical characteristics of the soil}

According to the results of ANOVA and Duncan test, the lowest percentage of sand and highest content of silt, potassium, $\mathrm{CaCO}_{3}$, and $\mathrm{EC}$ were found in the small hill area $(P$ value $<0.05)$ (Table 3$)$. Furthermore, based on the soil triangle, the soil texture in the small hill area, big hill area, flood plain, and mountainous area was sandy loam. The bare plain had loamy sand texture.

\section{Effect of geomorphological unit}

Based on the results of ANOVA, the characteristics of $P$. tomentosa have significant differences in the geomorphologic

Table 3 Physicochemical characteristics of the soil in the five geomorphological units

\begin{tabular}{lllllllllll}
\hline Geomorphological unit & $N$ & Sand (\%) & Silt (\%) & Clay (\%) & $K(\mathrm{PPM})$ & $P(\mathrm{PPM})$ & $N(\%)$ & $\mathrm{CaCO}_{3}(\%)$ & $\mathrm{EC}(\mathrm{dS} / \mathrm{m})$ & $\mathrm{pH}$ \\
\hline Mountain & 58 & $79.73(\mathrm{ab})$ & $10.50(\mathrm{bc})$ & $9.76(\mathrm{ab})$ & $44.37(\mathrm{c})$ & $5.01(\mathrm{a})$ & $0.02(\mathrm{a})$ & $9.55(\mathrm{~b})$ & $0.22(\mathrm{~b})$ & $7.82(\mathrm{a})$ \\
Big hill area & 32 & $72.06(\mathrm{ab})$ & $15.50(\mathrm{~b})$ & $12.42(\mathrm{a})$ & $283.07(\mathrm{~b})$ & $6.71(\mathrm{a})$ & $0.048(\mathrm{a})$ & $17.91(\mathrm{a})^{*}$ & $0.33(\mathrm{~b})$ & $7.71(\mathrm{a})$ \\
Bare plain & 5 & $84.40(\mathrm{a})$ & $5.84(\mathrm{~d})$ & $9.76(\mathrm{ab})$ & $43.76(\mathrm{c})$ & $7.54(\mathrm{a})$ & $0.30(\mathrm{a})$ & $5.80(\mathrm{~b})$ & $0.26(\mathrm{~b})$ & $7.80(\mathrm{a})$ \\
Flood plain & 14 & $78.40(\mathrm{ab})$ & $11.84(\mathrm{bc})$ & $9.76(\mathrm{ab})$ & $45.37(\mathrm{c})$ & $5.29(\mathrm{a})$ & $0.30(\mathrm{a})$ & $10.70(\mathrm{~b})$ & $0.20(\mathrm{~b})$ & $7.70(\mathrm{a})$ \\
Small hill area & 49 & $60.03(\mathrm{c})^{*}$ & $27.64(\mathrm{a})^{*}$ & $12.30(\mathrm{a})$ & $402.57(\mathrm{a})^{*}$ & $4.59(\mathrm{a})$ & $0.061(\mathrm{a})$ & $15.11(\mathrm{a})$ & $0.58(\mathrm{a})^{*}$ & $7.72(\mathrm{a})$ \\
\hline
\end{tabular}

The letters a-d indicate significant difference between different geomorphological units 
units $(P$ value $<0.05)$. The results of Duncan test showed that the highest aerial parts, length of roots, length of leaves, length of fruits, the number of seeds, and density of this plant species were found in the small hill area, while the plant species was absent in the mountain area. The quantitative characteristics of the plant species have intermediate conditions in the big hill area (Fig. 3).

\section{Effect of altitudinal gradient}

The results of ANOVA demonstrated that the altitudinal gradient (550-700; 700-900; 900-1100 m) had no effect on the quantitative characteristics of $P$. tomentosa ( $P$ value $>0.05$ ). Furthermore, the results of Pearson correlation showed no significant correlation between altitudinal gradient and quantitative characteristics of this plant $(P$ value $>0.05)$.

\section{Correlation between physicochemical parameters of soil and plant quantitative characteristics}

According to Pearson correlation results, the length of roots and height of aerial parts of the plant showed significant negative correlation with sand and positive correlation with content of silt, $\mathrm{K}$, content of $\mathrm{CaCO}_{3}$, and $\mathrm{EC}$ and no significant correlation with phosphorus, nitrogen, and $\mathrm{pH}$ (Table 4). Density of $P$. tomentosa exhibited negative correlation with sandy texture and positive correlation with $\mathrm{K}, \mathrm{EC}$, nitrogen, content of silt, and $\mathrm{CaCO}_{3}$. Other plant's quantitative characteristics (number of seeds, length of fruits, and length of leaves) did not show significant relationship with soil parameters (Table 4).

\section{Relationship between soil characteristics and plant characteristics}

The results of stepwise multivariate regression, in accordance with the results of Pearson correlation, showed that sand, content of silt, $\mathrm{K}$, content of $\mathrm{CaCO}_{3}$, and $\mathrm{EC}$ are the main variables influencing on quantitative characteristics of $P$. tomentosa (Table 5).

\section{Habitat modeling}

The results of Maxent modeling indicated that the environmental factors used for habitat modeling of $P$. tomentosa are suitable predictors for this plant. The best geological formation for this plant is the conglomerate formation, and the best geomorphological units were, respectively, small hill area, big hill area, flood plain, bare plain, and mountainous area (Fig. 4). According to the results, the area under the curve was high (0.91). The model was highly accurate in predicting the habitat of $P$. tomentosa (Fig. 5). The results of the Jackknife method revealed that the most important variables were, in order, geomorphological unit, $\mathrm{EC}$, content of $\mathrm{CaCO}_{3}$, content of silt, geological formation, and sand. Phosphorous, altitude, potassium, and nitrogen played a little role. Clay and $\mathrm{pH}$ showed the minimum effect on the habitat prediction of this plant (Fig. 6).

\section{Response curves}

According to the results of Maxent, geomorphological unit, content of $\mathrm{CaCO}_{3}, \mathrm{EC}$, content of silt, sand, and geological formation were the main environmental factors for predicting the potential habitat of $P$. tomentosa.

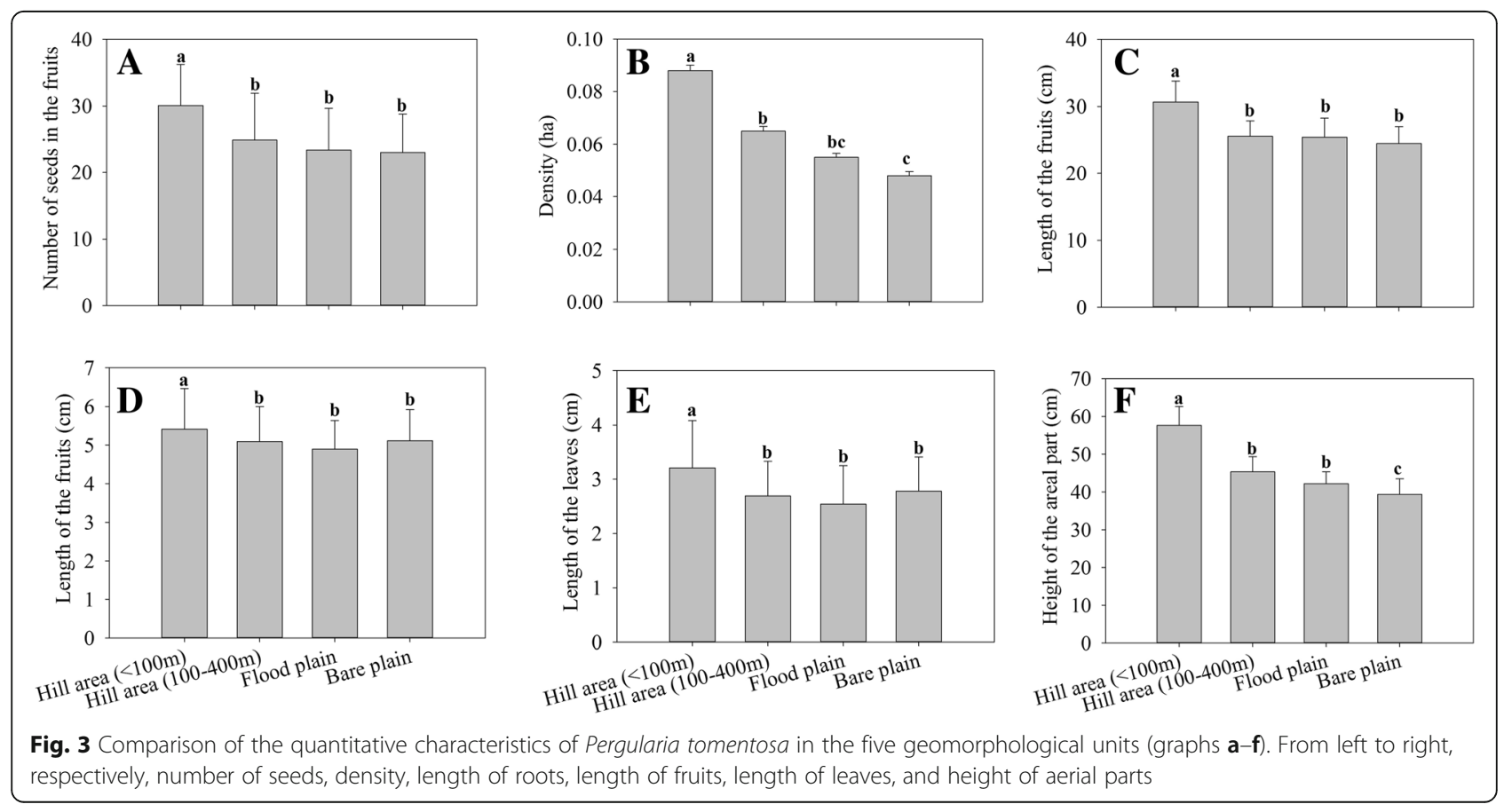


Table 4 Pearson correlation between physicochemical characteristics of the soil with quantitative characteristics of $P$. tomentosa

\begin{tabular}{|c|c|c|c|c|c|c|c|c|c|c|}
\hline Pearson correlation & $N$ & Sand & Silt & Clay & K & $\mathrm{CaCO}_{3}$ & EC & $P$ & $N$ & $\mathrm{pH}$ \\
\hline Length of root $(\mathrm{cm})$ & 15 & $-0.549^{* *}$ & $0.550^{* *}$ & 0.263 & $0.441^{* *}$ & $0.376^{*}$ & $0.302^{*}$ & $0.069^{\text {ns }}$ & $0.261^{\mathrm{ns}}$ & $-0.246^{\mathrm{ns}}$ \\
\hline High of aerial part $(\mathrm{cm})$ & 98 & $-0.568^{* *}$ & $0.582^{* *}$ & 0.219 & $0.460^{* *}$ & -0.339 & $0.512^{* *}$ & $0.271^{\mathrm{ns}}$ & 0.207 & $-0.216^{\mathrm{ns}}$ \\
\hline Density & 22 & $-0.642^{* *}$ & $0.640^{* *}$ & 0.235 & $0.551^{* *}$ & $0.037^{\mathrm{ns}}$ & $0.527^{* *}$ & $0.205^{\mathrm{ns}}$ & $0.324^{*}$ & $-0.245^{\mathrm{ns}}$ \\
\hline
\end{tabular}

** $(a=1 \%),{ }^{*}(a=5 \%)$

$\mathrm{ns}=\mathrm{ns}$ (not significant)

Based on the response curves (Fig. 7), there was a highly positive relationship among suitable habitats of this plant with $\mathrm{EC}$, content of silt, and $\mathrm{CaCO}_{3}$. However, sandy texture had a negative effect on distribution of this plant. Its habitat suitability is the greatest in areas with high content of $\mathrm{CaCO}_{3}, \mathrm{EC}$, and content of silt, and a minimum percentage of sand. Based on the geomorphological units, the lowest suitability was in the mountainous area (igneous formation). The small hill area had the best potential habitat for this plant. The second, third, and fourth degrees of suitability, respectively, were the big hill area, flood plain, and bare plain. Based on the suitability and importance of these units, we considered geomorphological units in five ranks (mountain $=1$, bare plain $=2$, flood plain $=3$, big hill area $=4$, and small hill area $=5)($ Fig. 7).

\section{Discussion}

A thorough investigation of the habitat suitability of $P$. tomentosa was carried out during our study. Firstly, we determined the effect of environmental variables (geological formations, geomorphological units, altitude, and soil parameters) on quantitative characteristics of $P$. tomentosa. Secondly, we applied maximum entropy model to predict the habitat suitability of $P$. tomentosa using the incidence data.

Table 5 Relationship between quantitative characteristics of Pergularia tomentosa and soil parameters. Statistic of $\beta$ shows the contribution of each soil variables on the quantitative characteristics of $P$. tomentosa. Regression equation is the formula for calculating each plant's quantitative characteristics

\begin{tabular}{|c|c|c|c|c|}
\hline Plant properties & Soil properties & $\beta$ & $P$ value & Regression equation \\
\hline \multirow[t]{8}{*}{ Length of roots } & Sand & 0.278 & 0.029 & \multirow[t]{8}{*}{ Length of roots $=0.278$ sand +0.280 silt $+0.193 \mathrm{~K}+0.164 \mathrm{CaCO} 3$} \\
\hline & Silt & 0.280 & 0.031 & \\
\hline & Potassium (K) & 0.193 & 0.041 & \\
\hline & $\mathrm{CaCO}_{3}$ & 0.164 & 0.047 & \\
\hline & EC & 0.127 & 0.079 & \\
\hline & R square & 0.287 & & \\
\hline & $\mathrm{F}$ & 4.76 & & \\
\hline & Constant & 3.91 & & \\
\hline \multirow[t]{8}{*}{ Height of aerial parts } & Sand & 0.324 & 0.022 & \multirow[t]{8}{*}{ Height of aerial parts $=0.324$ sand +0.351 silt $+0.213 k+0.261 \mathrm{EC}$} \\
\hline & Silt & 0.351 & 0.018 & \\
\hline & Potassium (K) & 0.213 & 0.034 & \\
\hline & $\mathrm{CaCO}_{3}$ & 0.153 & 0.061 & \\
\hline & EC & 0.261 & 0.038 & \\
\hline & R square & 0.319 & & \\
\hline & $\mathrm{F}$ & 5.08 & & \\
\hline & Constant & 6.39 & & \\
\hline \multirow[t]{8}{*}{ Density } & Sand & 0.372 & 0.018 & \multirow[t]{8}{*}{ Density $=0.327$ sand +0.369 silt $+0.281 \mathrm{~K}+0.259 \mathrm{EC}$} \\
\hline & Silt & 0.369 & 0.015 & \\
\hline & Potassium (K) & 0.281 & 0.033 & \\
\hline & $\mathrm{CaCO}_{3}$ & 0.259 & 0.040 & \\
\hline & EC & 0.259 & 0.040 & \\
\hline & R square & 0.331 & & \\
\hline & $\mathrm{F}$ & 6.73 & & \\
\hline & Constant & 3.01 & & \\
\hline
\end{tabular}



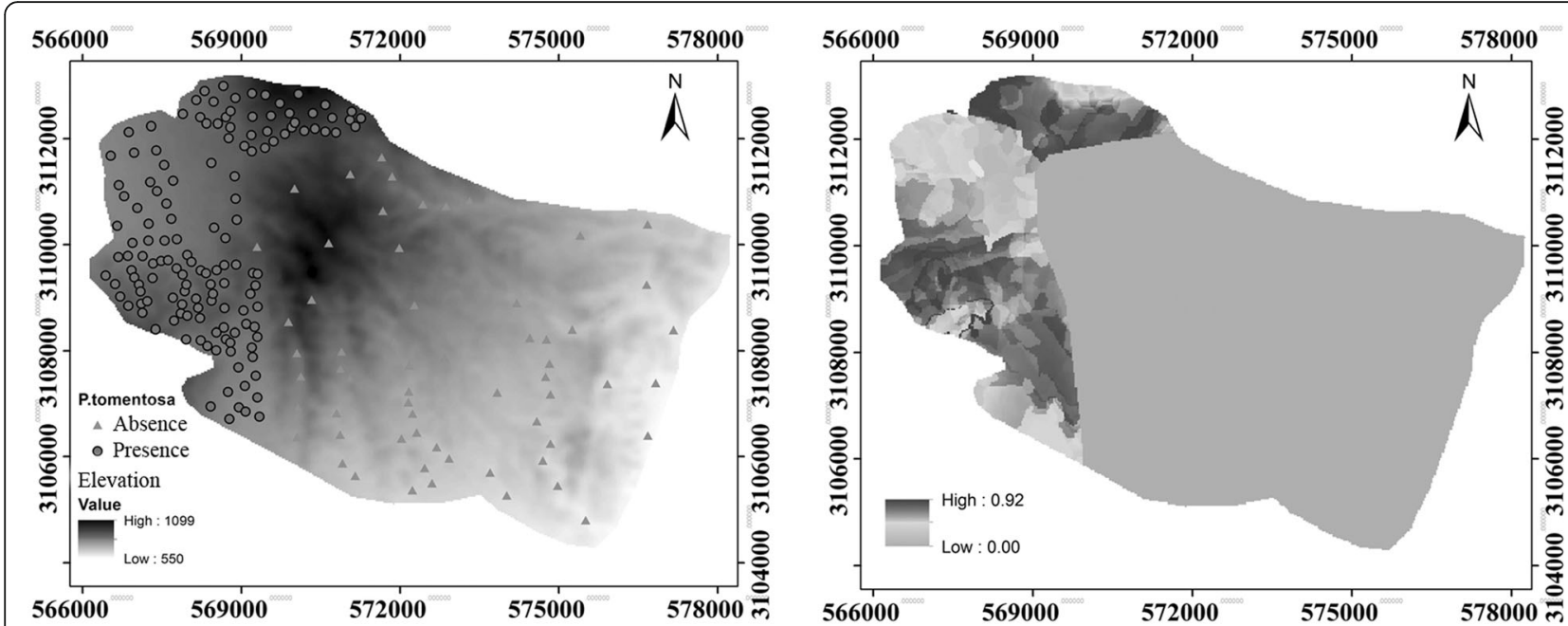

Fig. 4 Location of the absence and presence data (left) and prediction map based on the presence points (right)

\section{Environmental variables and plant quantitative} characteristics

In the study area, two geological formations were distinguishable. However, only the conglomerate formation (small and big hill areas, and bare and flood plains) had suitable conditions to serve as the habitat of $P$. tomentosa. Many field surveys with the guidance of local people confirmed the negative effect of the igneous formation in growing of $P$. tomentosa. These results indicated that geomorphology and geology could be the main factors shaping habitat distribution for this plant species, and their importance is due to the content of silt, $\mathrm{CaCO}_{3}, \mathrm{~K}$, and EC of the soil. Therefore, the suitability of the small hill area for growing of the plant species could be related to the soil fertility, moisture, and silt content. More precisely, silt content could influence distribution of $P$. tomentosa by affecting the soil moisture, fertility, ventilation, and root growth. Particularly, in the arid rangelands, moisture availability and silt content are the most important variables in habitat productivity (Zegeye et al. 2006; Youssef and Al-Fredan 2008; Abdollahi et al. 2013). In other words, decreasing of soil

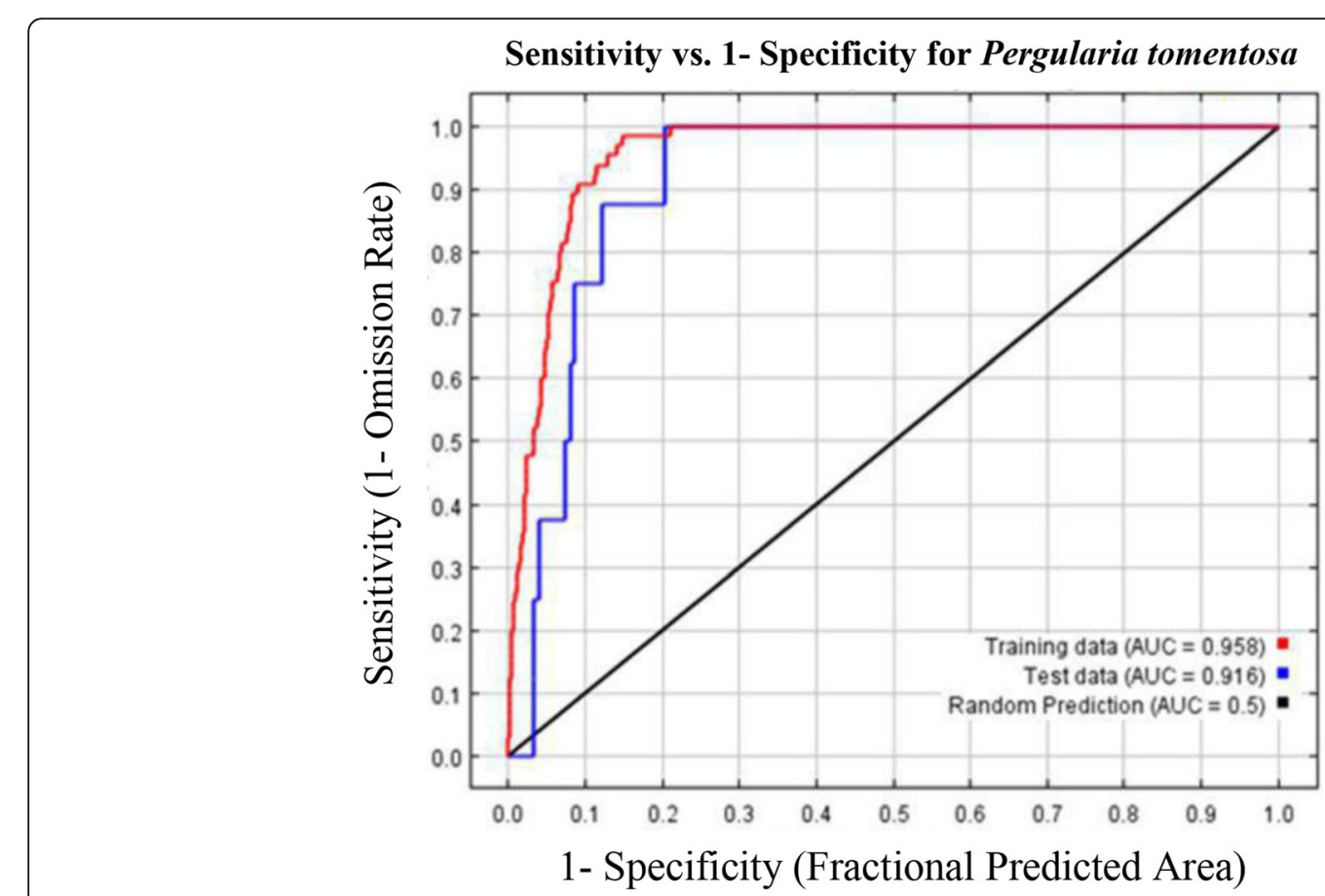

Fig. 5 The receiver operating characteristic (ROC) for $P$. tomentosa 


\section{Jackknife of regularized training gain for $P$. tomentosa}

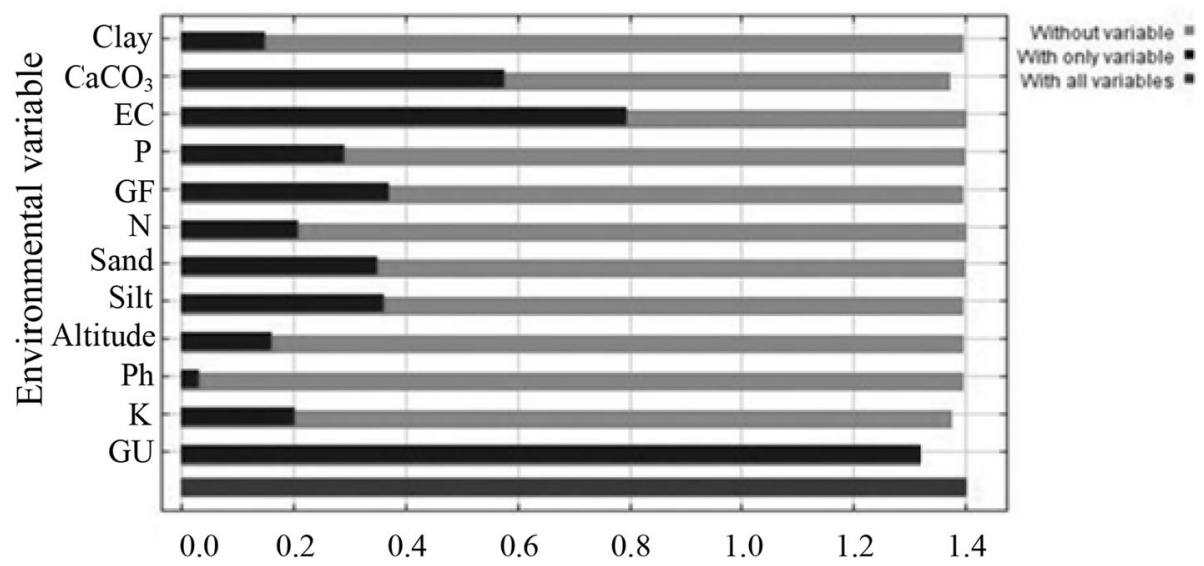

Fig. 6 Jackknife results for the importance of the environmental variables. The main predictors are geomorphological unit, EC, content of CaCO geological formation (GF), content of silt, and sand, respectively

silt content might be a limiting factor for growing of $P$. tomentosa in arid rangelands of Iran. In addition, previous studies showed that dense soil due to the high content of clay had low soil moisture storage capacity and it was a restricting factor on the distribution of many plant species (Pilania and Panchal 2016). Although, in our study area, soil silt content was relatively high $(28 \%)$, the clay content was low (12.5\%), subsequently an increase in soil porosity, water holding, and field capacity. These conditions could be enough to increase the percentage cover of the species on the hills. In addition, the presence of $P$. tomentosa was strongly correlated to the $\mathrm{CaCO}_{3}$ content. We argue that calcium is able to improve the structure of soil (Shabala et al. 2003; Pilania and Panchal 2016) having a positive effects on our plant species density. It seems that the species prefer soil with higher EC. Since higher EC increases the solubility of the soil salt concentration (Maiti 2003), it could be proper for growing of our studied species. Our results disagree with Pilania and Panchal (2014)'s findings in which they showed that high content of clay along with high value of EC had a negative effect on the vegetation.

In general, our results showed that compared to the soil properties, geological formations and geomorphological units played more important roles in the habitat suitability of $P$. tomentosa. Therefore, our results in coordination with the reports of other studies (Panchal and Pandey 2002; Vogiatzakis et al. 2003) showed that changing geological formations is an important factor which influences soil parameters and plant distribution. In addition, the results of Abdollahi et al. (2013) in arid rangelands of Iran revealed that changing of geological formation can affect soil texture, and in turn, soil fertility, EC, and content of $\mathrm{CaCO}_{3}$ can be affected by soil texture. They concluded that plant distribution is under the influence of this hierarchy of the above environmental variables. Also, the results of Higgins et al. (2011) demonstrated that geological formation is one of the main environmental factors in determining plant habitat. Our previous researches (Erfanzadeh and Hosseini Kahnuj 2015; Erfanzadeh et al. 2014) regarding the aboveground vegetation and soil seed bank in these rangelands also clarified the considerable effect of the geological formations and geomorphological units on the aboveground vegetation and soil parameters $(P$. tomentosa was absent in the aboveground vegetation and in the soil seed bank in the igneous formation and mountainous area).

Regarding the effect of altitude and its influenced variables such as climate, our hypothesis supposed that altitude can have significant effect on other variables (climate and solar radiation), and it plays an important role on the quantitative characteristics and presence of $P$. tomentosa; however, the results did not confirm this hypothesis. The irregular distribution of $P$. tomentosa demonstrated that in contrast to the importance of the altitude, other environmental variables (geology and geomorphology) can be the main factors affected the distribution and characteristics of arid rangeland plants. However, the results of Hosseini (2016) showed that quantitative characteristics of soil seed bank (density and richness) and physiological characteristics (quality and quantity of extract) of $P$. tomentosa under the canopy of Pteropyrum aucheri (in shadow, with lower solar radiation) were significantly higher than outside the canopy cover. Consequently, in the present study, perhaps the low altitudinal gradient $(600 \mathrm{~m})$ cannot demonstrate the effect of climate and solar radiation on the plant's characteristics. Other findings (Ashrafzadeh et al. 2015) showed that altitudinal gradient less than $1000 \mathrm{~m}$ could 


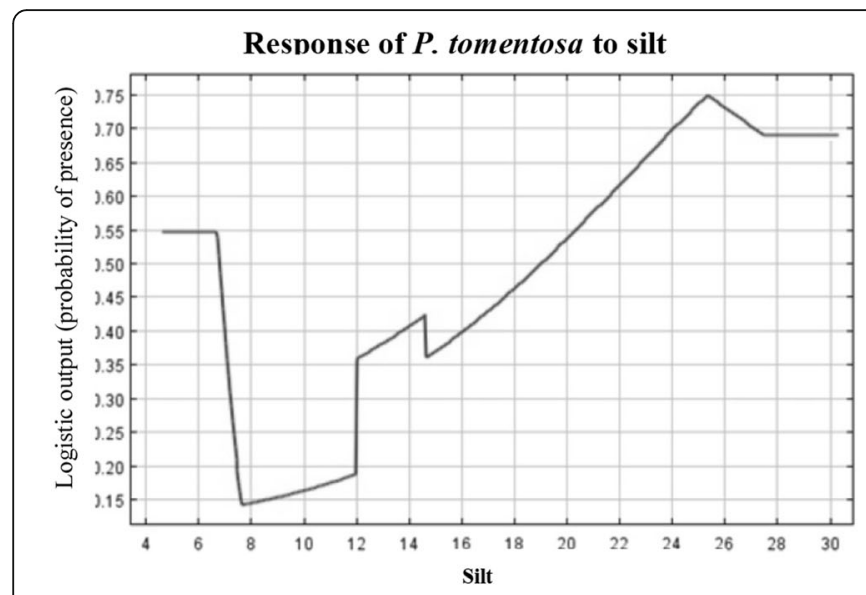

Response of $P$. tomentosa to geological formations

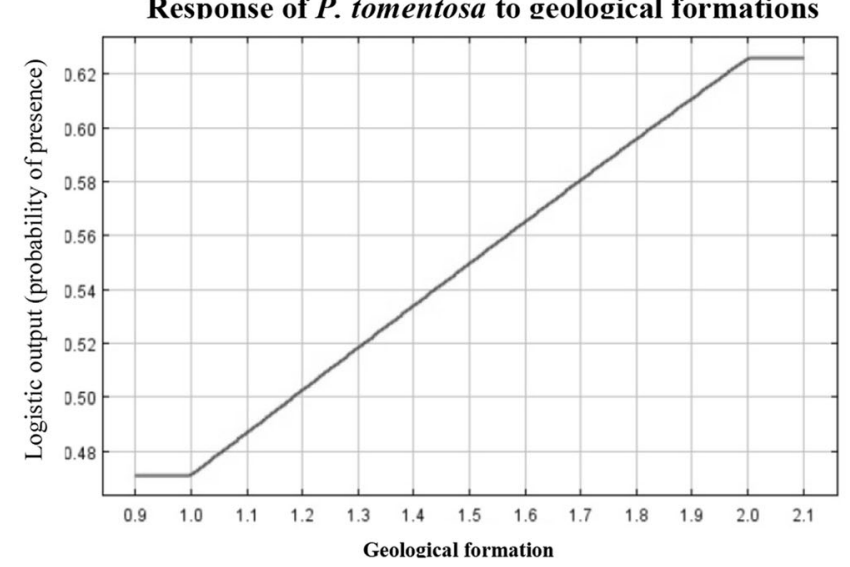

Response of P. tomentosa to EC

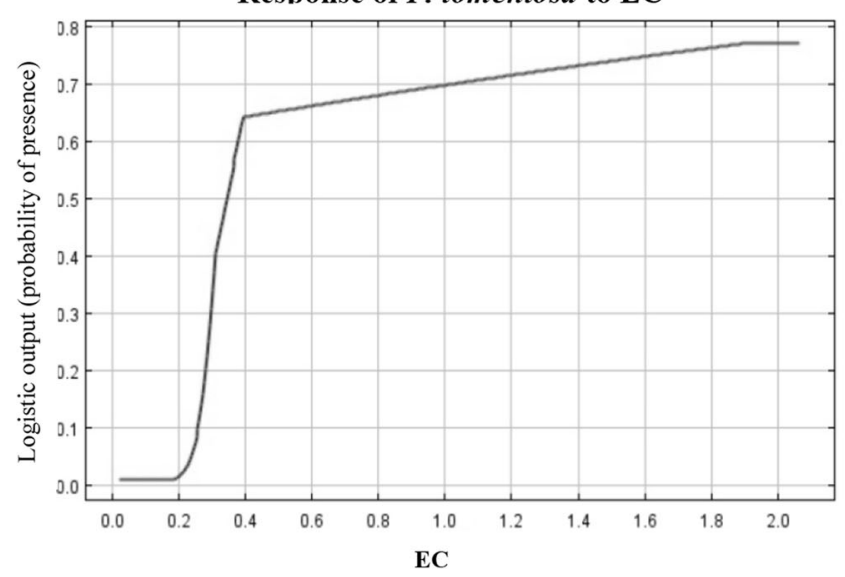

Fig. 7 Response curves of the most important predictors for $P$. tomentosa

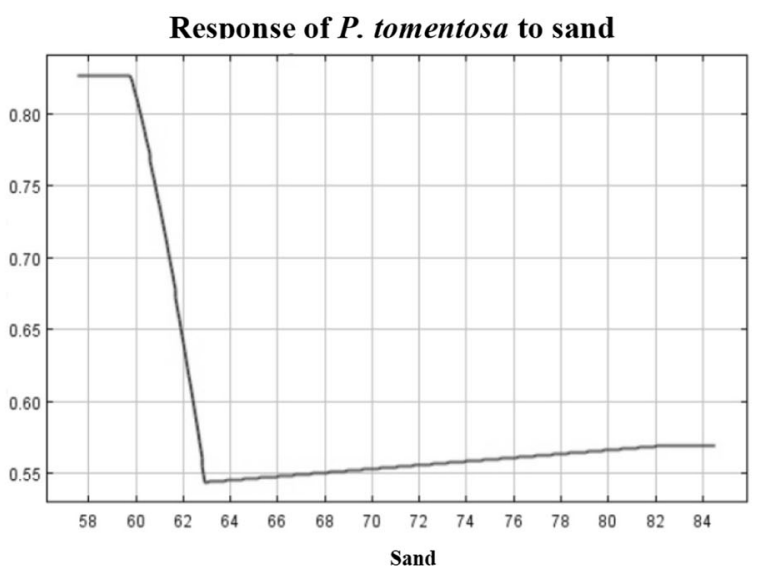

Response of $\boldsymbol{P}$. tomentosa to geomorphological units

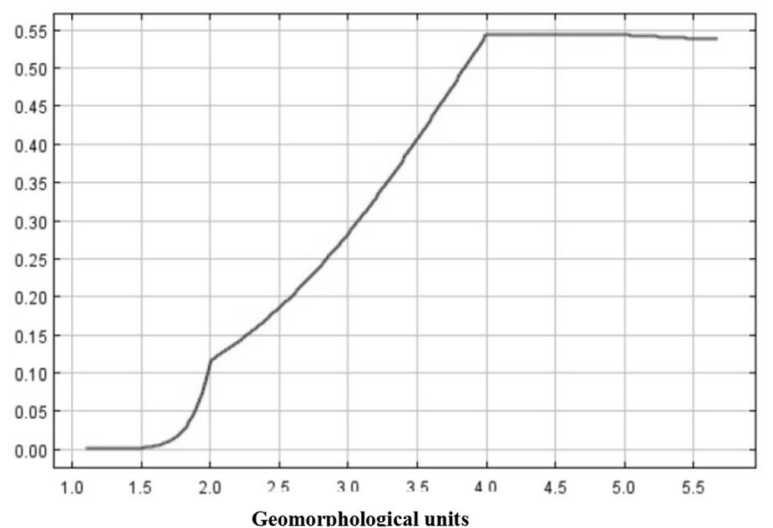

Response of $\boldsymbol{P}$. tomentosa to $\mathrm{CaCO}_{3}$

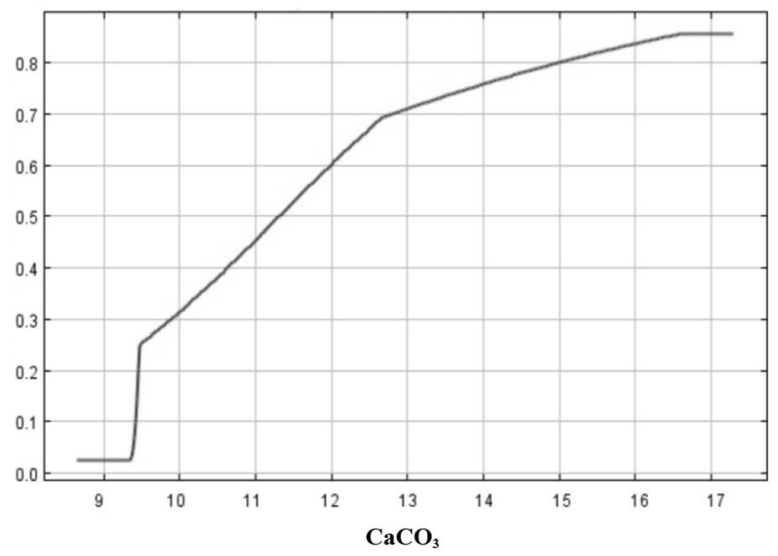

not affect climate and plant distribution. Findings suggest that in this study area, climate is not influenced by the low altitudinal gradient $(600 \mathrm{~m})$.

Overall, the results showed that $P$. tomentosa spread in the relatively low density in the whole area, and even in the conglomerate formation as a suitable habitat, the density was very low ( 0.069 per hectare). These results suggested that conservation, recovery, and development of the $P$. tomentosa should be a priority in the rangelands, southeastern Iran. Finally, we believe that recent drought could be a prominent factor in decreasing of canopy cover of $P$. tomentosa. Moreover, although the species is unpalatable for grazing, overgrazing in the study area could indirectly eradicate the species, e.g., trampling. In addition, personal observation in the field showed that the species is able to produce a large number of fruits (spiny follicles) and seeds (12-44). Therefore, low density of the species in the study area shows 
that the plant species probably is not also able to have sexual production that needs to be considered in the future studies. However, the low density of the species were not reported in the other habitats in the Middle East (see also Goyder's 2006; Chaudhary and Le Houérou 2006; Gallacher and Hill 2006; Al-Rowaily et al. 2015).

\section{Predicting the habitat}

The results of the Maxent modeling, combined with the above explanations, showed that geomorphological unit, $\mathrm{CaCO}_{3}, \mathrm{EC}$, silt content, sand content, and geological formation are respectively the main predictors for identifying appropriate habitat for the plant species. The habitat suitability of $P$. tomentosa demonstrated strong negatively correlation with sand content and high positively correlation with silt content, $\mathrm{CaCO}_{3}$, and $\mathrm{EC}$. Therefore, according to the Maxent results, the best potential conditions for existing of this species belonged to the small hill area in conglomerate formation. In addition, the Maxent could be a reliable method (ROC $=0.91$ ) for predicting this plant's habitat. If species distribution models can determine the suitability of habitat, they can be a valuable conservation method for this rare species, and maximum entropy is an appropriate method to rank potential habitat (Gogol-Prokurat 2011; Phillips et al. 2006; Marmion et al. 2009; Kumar et al. 2009). Finally, we conclude that soil parameters are important variables in determining the plant's habitat, but they rank second.

\section{Conclusion}

If the effect of the environmental variables on the rangeland plant properties were directly measured, and if their habitat suitability was indirectly predicted by using a reliable model such as maximum entropy, appropriate information could be provided to decision processes about the conservation and reclamation efforts for valuable rangeland plants species such as $P$. tomentosa in the arid regions. P. tomentosa is poisonous to animals; therefore, its fate might depend on the human efforts, environmental factors (e.g., drought) and other livestock activities such as compacting of soil by trampling.

Moreover, our results demonstrated that contrary to expectations about the role of topography and soil properties, some other environmental variables, such as geomorphological units and geological formation, play the prominent roles in plants' habitat suitability. Soil parameters could be significantly affected by these factors. Maxent was established to be a reliable modeling method for predicting the potential habitat of this endangered plant. The best potential habitat for P. tomentosa is the small hill area in conglomerate formation due to the considerable content of silt, $\mathrm{CaCO}_{3}, \mathrm{EC}$, and soil fertility.

\section{Abbreviations}

GPS: Global Positioning System; ROC: Receiver operating characteristic

\section{Acknowledgements}

We would like to acknowledge the University of Tehran for technical and financial support. The authors are grateful for the sponsorship of the Ministry of Science, Research and Technology of Iran during the sabbatical of S.H.H.K. We sincerely thank the natives of these rangelands (tribe of Shahryari Sarhaddi) for their help in all steps of the field visits and data sampling. We thank Dr. V. Devictor for his valuable guidance on an earlier draft of this article.

Funding

This research was supported by the University of Tehran, Iran.

Availability of data and materials

The data that supported these results of this research are available from the corresponding author on reasonable request.

\section{Authors' contributions}

HA, MA, and MAZ conceived of the research, led its design, and performed the statistical analysis. SHHK participated in all steps (designing, field work and ...). SP and RKH participated in the design of the work and edited the manuscript draft. All authors approved the final manuscript.

Ethics approval and consent to participate

Not applicable

Consent for publication

Not applicable

Competing interests

The authors declare that they have no competing interests.

\section{Publisher's Note}

Springer Nature remains neutral with regard to jurisdictional claims in published maps and institutional affiliations.

\section{Author details}

${ }^{1}$ Department of Plant Biology, University of Jiroft, Jiroft, Kerman Province, Iran. ${ }^{2}$ Department of Reclamation of Arid and Mountainous Regions, Natural Resources Faculty, University of Tehran, Tehran, Iran. ${ }^{3}$ Department of Horticultural Science, Tarbiat Modares University (TMU), Tehran, Iran.

${ }^{4}$ Department of Rangeland Management, Tarbiat Modares University (TMU), Tehran, Iran. ${ }^{5}$ Department of Pharmacy, University of Salerno, Salerno, Italy. ${ }^{6}$ Department of Pathobiology, Faculty of Veterinary Science, Shahid Bahonar University of Kerman, Kerman, Iran.

Received: 9 June 2018 Accepted: 21 October 2018

Published online: 21 November 2018

\section{References}

Abdollahi J, Naderi H, Mirjalili MR, Tabatabaeezadeh MS. Effects of some environmental factors on growth characteristics of Stipa barbata species in steppe rangelands of Nodoushan-Yazd. J Rang and Dest Res. 2013;20(1):13044.

Al-Jabri SAH. Chemical and bio-analytical studies on Pergularia tomentosa and species from the Mentha genus, Ph.D. thesis, University of Leicester; 2013. p. 259.

Al-Rowaily SL, El-Bana MI, Al-Bakre BDA, Assaeed CAM, Basharat AAK. Effects of open grazing and livestock exclusion on floristic composition and diversity in natural ecosystem of Western Saudi Arabia. Saudi J Biol Sci. 2015;22:430-7.

Al-Said M, El-Olemy MM, Elhag HM. Biotechnological production of biologically active metabolites by plant cell culture techniques. Saudi Arabia: KACsST (King Abdulaziz City for Science and Technology); 2002. p. 218-56. 
Arafa HI, Alberto P, Balestrieri ML, Mahalel UA, Springuel IV, Oleszek W, Pizza C, Piacente $\mathrm{S}$. Cardenolide glycosides from Pergularia tomentosa and their proapoptotic activity in Kaposi's sarcoma cells. J Nat Prod. 2006;69:1319-22.

Ashrafzadeh M, Erfanzadeh R, Hoseini Kahnouj SH. Effects of soil chemical properties on forage quality in dry rangelands in the south of Fars province. J Ran and Des Res. 2015;22(2):383-91 (In Persian).

Babaamer Z, Sekhari L, Al-Jaber H, Al-Qudah M. Extraction and identification of triterpenoids from Pergularia tomentosa L. ANN Sci Technol. 2013;5:1-4.

Babaamer ZY, Sakhri L, Al-Jaber HI, Al-Qudah MA, Abu Zarga MH. Two new taraxasterol-type triterpenes from Pergularia tomentosa growing wild in Algeria. J Asian Nat Prod Res. 2012;14:1137-43.

Bekheet SH, Abdel-Motaal FF, Mahalel UA. Antifungal effects of Ficus sycomorus and Pergularia tomentosa aqueous extracts on some organs in Bufo regularis treated with Aspergillus niger. TISSUE CELL. 2011;43:398-404.

Bellakhdar J. La Pharmacopee Marocaine Traditionnelle. Médecine arabe ancienne et savoirs populaires. Paris: Ibis Press; 1998.

Black CA. Method of soil analysis. American society of agronomy. 1979;2:771.

Buehler EC, Ungar LH. Maximum entropy methods for biological sequence modeling. BIOKDD; 2001. p. 60-4.

Byeon DH, Jung S, Lee WH. Review of CLIMEX and MaxEnt for studying species distribution in South Korea. J Asia-Paci Biodi. 2018;11:325-33.

Chaudhary SA, Le Houérou HN. The rangelands of the Arabian Peninsula. Secheresse. 2006;17(1):179-94.

Deleo JM. Receiver operating characteristic laboratory (ROCLAB): software for developing decision strategies that account for uncertainty. College Park: Proceedings of the 2nd International Symposium on Uncertainty Modeling and Analysis; 1993. p. 25-8.

Elith J, Graham CH, Anderson RP, Dudk M, Ferrier S, Guisan A, Hijmans RJ, Huettmann F, Leathwick JR, Lehmann A, Li J, Lohmann LG, Loiselle BA Manion G, Moritz C, Nakamura M, Nakazawa Y, Overton JM, Peterson AT, Phillips SJ, Richardson K, Scachetti-Pereira R, Schapire RE, Soberón J, Williams S, Wisz MS, Zimmermann NE. Novel methods improve prediction of species' distributions from occurrence data. Ecography. 2006;29:129-51.

Erfanzadeh R, Hosseini Kahnuj SH. Soil seed bank characteristics in relation to distance from watering-points in arid ecosystems (case study: Kahnuj, Kerman Province). ECOPERSIA. 2015;3:975-86.

Erfanzadeh R, Hosseini Kahnuj SH, Pétillon J. Crude protein content does not determine the preference value of plant species for the Raini goat (Capra aegagrus hircus L.) in dry rangelands. DESERT. 2014;19:35-43.

Fielding $\mathrm{AH}$, Bell JF. A review of methods for the assessment of prediction errors in conservation presence/absence methods. Environ Conserv. 1997;24:38-49.

Gallacher DJ, Hill JP. Effects of camel vs oryx and gazelle grazing on the plant ecology of the Dubai desert conservation reserve. In: Mohamed AMO, editor. Pages reclaiming the desert: towards a sustainable environment in arid lands. Proceedings of the Third Joint UAE-Japan Symposium on Sustainable GCC Environment and Water Resources (EWR2006). Abu Dhabi: Taylor \& Francis; 2006. p. 85-95.

Gogol-Prokurat M. Predicting habitat suitability for rare plants at local spatial scales using a species distribution model. Ecol Appl. 2011;21:33-47.

Goyder DJ. A revision of the genus Pergularia L. (Apocynaceae: Asclepiadoideae). Kew Bull. 2006;61:245-56

Green PWC, Veitch NC, Stevenson PC, Simmonds MSJ. Cardenolides from Gomphocarpus sinaicus and Pergularia tomentosa (Apocynaceae: Asclepiadoideae) deter the feeding of Spodoptera littoralis. Arthropod Plant Interact. 2011;5:219-25.

Guisan A, Zimmermann NE, Elith J, Graham CH, Phillips S, Peterson AT. What matters for predicting the occurrences of trees: techniques, data, or species characteristics? Ecol Monogr. 2007;77:615-30.

Hammiche H, Maiza K. Traditional medicine in Central Sahara: pharmacopoeia of Tassili N'ajjer. J Ethnopharmacol. 2006;105:358-67.

Heneidak S, Grayer RJ, Kite GC, Simmonds MSJ. Flavonoid glycosides from Egyptian species of the tribe Asclepiadeae (Apocynaceae, subfamily Asclepiadoideae). Biochem Syst Ecol. 2006;34:575-84.

Hernández PA, Graham CH, Master LL, Albert DL. The effect of sample size and species characteristics on performance of different species distribution modeling methods. Ecography (Cop). 2006;29:773-85.

Higgins MA, Ruokolainen K, Tuomisto H, Llerena N, Cardenas G, Phillips OL, Vásquez R, Räsänen M. Geological control of floristic composition in Amazonian forests. J Biol. 2011;38:2136-49.

Hosseini FS. Canopy effect of Pteropyrum aucheri on species richness and density of soil seed bank of P. tomentosa. Master thesis, Tarbiat Modares University (TMU); 2016. p. 78.
Hosseini Kahnouj SH, Ayyari M, Azarnivand H, Piacente S, Zare Chahouki MA. Pergularia tomentosa, from traditional uses to ecology and phytochemistry. J Med Plants. 2017;16(63):108-18.

Hosseini SZ, Kappas M, Zare Chahouki MA, Gerold G, Erasmi S, Emam Rafiei A. Modelling potential habitats for Artemisia sieberi and Artemisia aucheri in Poshtkouh area, central Iran using the maximum entropy model and geostatistics. Ecol Inform. 2013;18:61-8.

Hussein HI, Al-Rajhy D, El-Shahawi Fl, Hashem SM. Molluscicidal activity of Pergularia tomentosa $(\mathrm{L})$, methomyl and methiocarb against land snails. Int J Pest Manage. 1999;45:211-3.

Jackson DA. Stopping rule in principal component analysis - a comparison of heuristic and statistical approaches. J Ecol. 1993;74(8):2204.

Jackson ML. Soil chemical analysis. New Delhi: Prentice-Hall of India; 1967. p. 489.

Jung JM, Lee WH, Jung S. Insect distribution in response to climate change based on a model: review of function and use of CLIMEX. Entomological Research. 2016:46:223-35.

Kumar S, Neven LG, Zhu H, et al. Assessing the global risk of establishment of Cydia pomonella (Lepidoptera: Tortricidae) using CLIMEX and MaxEnt niche models. J Econ Entomol. 2015;108:1708-19.

Kumar S, Spaulding SA, Stohlgren TJ, Hermann KL, Schmidt TS, Bahls LL. Potential habitat distribution for the freshwater diatom Didymosphenia geminata in the continental US. J JEAE. 2009;7(8):415-20.

Lahiji AA, Jafari M, Zare Chahooki MA, Dadaopokshi MA. The effects of different agricultural uses of drylands on soil fertility factors in Hamadan Province (Chopok-loo area, Bahar City): a case study. Int j agric crop sci. 2012;4-10:586-90.

Maiti SK. Handbook of methods in environmental studies. Air, noise, soil and overburden analysis, vol. Vol. 2. Jaipur: ABD Publishers; 2003.

Marmion M, Parviainen M, Luoto M, Heikkinen RK, Thuiller W. Evaluation of consensus methods in predictive species distribution modelling. Divers. Distributions. 2009;15:59-69.

Negga HE. Predictive modelling of amphibian distribution using ecological survey data: a case study of Central Portugal. Enschede: Master thesis International Institute for Geo-information Science and Earth Observation; 2007.

Panchal NS, Pandey AN. Study on soil properties and their influence on vegetation in Western Region of Gujarat State in India. Beijing: 12th ISCO conference; 2002. p. 610-5.

Phillips SJ, Anderson RP, Schapire RE. Maximum entropy modeling of species geographic distributions. Ecol Model. 2006;190:231-59.

Piacente S, Masullo M, De Nève N, Dewelle J, Hamed A, Kiss R, Mijatovic T. Cardenolides from Pergularia tomentosa display cytotoxic activity resulting from their potent inhibition of Na+/K+-ATPase. J Nat Prod. 2009;72:1087-91.

Pilania PK, Panchal NS. Soil and plant relation at Little Rann of Kutch of Gujarat in western India. Int J Adv Res. 2014;7:1-10.

Pilania PK, Panchal NS. Influence of soil properties on plant density and species richness of saline desert. An Biol. 2016:38:81-90.

Shabala S, Shabala L, Volkenburgh EV. Effect of calcium on root development and root ion fluxes in salinised barley seedlings. Funct Plant Biol. 2003;30: 507-14.

Shinkafi SA. Antidermatophytic activities of column chromatographic fractions and toxicity studies of Pergularia tomentosa L. and Mitracarpus scaber Zucc. Used in the treatment of dermatophytoses. Adv. Med. Plant Res. 2014;2:7-15.

Soltanipur MA. Medicinal plants of Geno. Iranian Journal of Pajouhesh \& Sazandegi. 2005:69:27-37 (In Persian).

Vogiatzakis IN, Griffiths GH, Mannion AM. Environmental factors and vegetation composition, Lefka Ori Massif, Crete, S Aegean. Glob Ecol Biogeogr. 2003;12:131-46.

Warren DL, Seifert SN. Ecological niche modeling in Maxent: the importance of model complexity and the performance of model selection criteria. Ecol Appl. 2011;21:335-42.

Yakubu R, Jibril FM, Lukman A, Sheikh F. Trends for antioxidant power of phytochemicals from Pergularia tomentosa L. (Asclepiadaceae) whole plant. SAJP. 2015;4:74-80

Youssef AM, Al-Fredan MA. Community composition of major vegetations in the coastal area of Al-Uqair, Saudi Arabia in response to ecological variations. Pak J Biol Sci. 2008;8(4):713-21.

Zegeye $\mathrm{H}$, Teketay D, Kelbessa E. Diversity, regeneration status and socioeconomic importance of the vegetation in the island of Lake Ziway, southcentral Ethiopia. Flora. 2006;201:483-98. 